\title{
Drug utilization research in coinfected patients with tuberculosis and HIV/AIDS
}

\author{
Isabella Sant'Ana LOBO ${ }^{1}$, Wânia da Silva CARVALHO ${ }^{1}$, Natália Helena RESENDE ${ }^{1}$ \\ ${ }^{1}$ Federal University of Minas Gerais \\ Corresponding author: Lobo IS, isabellasantana.bh@gmail.com \\ Submitted: 20-12-2018 Resubmitted: 02-03-2020 Accepted: 10-03-2020 \\ Peer review: blind reviewer and Ronaldo Rodrigues Costa
}

\begin{abstract}
Objectives: This study aims to describe and classify the drugs prescribed for coinfected patients treated at a reference hospital. Methods: A retrospective cross-sectional study with analysis of information contained in a database prepared in an earlier study The Anatomical Therapeutic Chemical (ATC) classification system was used to classify the prescribed drugs. Results: Eighty-one coinfected individuals participated in the study, with a mean age of 40 years old and numerous comorbidities. A total of 147 drugs were found and, when the frequency of prescription was evaluated, the most used therapeutic groups were anti-infectious, considering the large number of opportunistic infections (OIs) presented by coinfected patients, followed by feeding tract drugs used to treat adverse drug reactions. We could observe that $73 \%$ of the evaluated population had a CD4+ T lymphocyte count $<200$ cells $/ \mathrm{mm} 3$ and a high viral load, indicating advanced immunodeficiency. Conclusion: It is necessary to develop strategies aimed at coinfected patients, such as specialized care, early diagnosis and appropriate treatment of coinfection. It is also important to carry out more studies on the use of drugs among coinfected patients to create actions directed to this population that may contribute to the rational use of drugs.
\end{abstract}

Keywords: tuberculosis, HIV, coinfection, opportunistic infections, drug utilization.

\section{Estudo da utilização de medicamentos em pacientes coinfectados com tuberculose e HIV/AIDS}

\begin{abstract}
Resumo
Objetivos: Descrever e classificar os medicamentos prescritos para pacientes coinfectados atendidos em um hospital de referência. Métodos: Estudo do tipo transversal retrospectivo com análise das informações contidas em um banco de dados elaborado em um estudo anterior. O sistema de classificação Anatomical Therapeutic Chemical (ATC) foi utilizado para classificar os medicamentos prescritos. Resultados: participaram do estudo 81 indivíduos coinfectados, com média de idade de 40 anos e inúmeras comorbidades. 0 número total de medicamentos utilizados pelos pacientes foi de 147 e ao se avaliar a frequência de prescrição, os grupos terapêuticos mais utilizados foram dos anti-infecciosos, considerando a grande quantidade de Infecções Oportunistas (IO) apresentadas pelos pacientes coinfectados. Seguido dos medicamentos do trato alimentar utilizados para tratar as reações adversas a medicamentos. Observou-se que $73 \%$ da população avaliada apresentou contagem de linfócitos T CD4+ < 200 células/mm3 e carga viral elevada, indicando imunodeficiência avançada. Conclusões: É necessário o desenvolvimento de estratégias voltadas aos pacientes coinfectados, como atendimento especializado, diagnóstico precoce e tratamento adequado da coinfecção. Faz-se importante também a realização de mais estudos de utilização de medicamentos entre pacientes coinfectados para que sejam criadas ações direcionadas a esta população que contribuam para o uso racional de medicamentos.
\end{abstract}

Palavras-chave: tuberculose, HIV, coinfecção, infecções oportunistas, uso de medicamentos.

\section{Introduction}

Human immunodeficiency virus (HIV) infection represents a major challenge in tuberculosis (TB) control around the world, as TB is the leading cause of death among people living with HIV (PLHIV), accounting for about one in three deaths related to acquired immunodeficiency syndrome (AIDS). ${ }^{1}$ In 2017, the risk of developing TB among the 37 million PLHIVs was 20 times greater than the risk in the rest of the world population. ${ }^{2}$

According to the World Health Organization (WHO), in 2017, of an estimated 10 million cases of TB in the world, 9\% were PLHIVs. ${ }^{2}$ In the same year, the proportion of TB-HIV coinfection in Brazil was $9.6 \%$ concerning the 72,000 reported cases of TB in the country. ${ }^{3}$ 
Early diagnosis of coinfection allows for a timely initiation of antiretroviral therapy (ART) and increases patient survival, providing a better outcome of the TB treatment. ${ }^{4}$ ART is recommended for all coinfected patients, regardless of the clinical form of TB presentation. Its initiation during TB treatment reduces individuals' mortality and promotes better integration between TB and HIV services. ${ }^{5}$

The initial ART scheme is indicated for coinfected and treatmentvirgin patients and includes tenofovir, lamivudine, and efavirenz (TDF/3TC/EFV) Combined Fixed-Dose -3 in $1 .{ }^{5}$ While the TB treatment scheme is formed by combining four drugs into one Combined Fixed-Dose tablet: rifampicin (R), isoniazid $(H)$, pyrazinamide ( $Z$ ) and ethambutol (E) for two months (intensive phase) and, in a second phase, $\mathrm{R}$ and $\mathrm{H}$ for a further four months (maintenance phase), also known as 2 RHZE/4RH scheme. ${ }^{6}$

Individuals undergoing coinfection treatment usually have lower adherence to one or both treatments, due to the therapeutic scheme involving a high number of drugs. This increases the risk of drug resistance, treatment relapses, death and can also prolong the severity of both diseases. ${ }^{7-8}$

Medicinal Use Studies (Estudos de Utilização de Medicamentos, EUMs) are essential in the detection, analysis, and solution of problems arising from the inappropriate use of medicines. ${ }^{9}$ In the context of coinfection, EUMs are important as they provide a better understanding of the drug consumption characteristics among patients and allow the identification of consumptionassociated factors, such as for opportunistic infections (OI) that commonly affect PLHIVs. ${ }^{5,10}$

In this context, this study aims to identify and classify the drugs prescribed for TB and HIV/AIDS coinfected patients in a reference hospital in order to establish actions aimed at promoting the rational use of drugs in this population.

\section{Methods}

The study was of the retrospective cross-sectional type, with analysis of the information contained in a database built from the research project entitled "Pharmaceutical Care applied to patients living with tuberculosis and HIV/AIDS in a reference hospital of Belo Horizonte", carried out between September 2015 and December 2016 at the Eduardo de Menezes Hospital (Hospital Eduardo de Menezes, HEM) of the Minas Gerais Hospital Foundation (Fundação Hospitalar de Minas Gerais, FHEMIG) in Belo Horizonte. The study was approved by the Research Ethics Committee of the Federal University of Minas Gerais (Universidade Federal de Minas Gerais, UFMG) and of the FHEMIG on June $25^{\text {th }}, 2014$, under the CAAE number: 23692713.2.3001.5124.

Adult patients diagnosed with pulmonary and/or extrapulmonary TB and HIV/AIDS, accompanied in the HEM, aged 18 years old or older, were included in the study; they began treatment for TB as of September 2015 and agreed to participate in the study by signing the Free and Informed Consent Form (FICF).

The data was collected through interviews with semi-structured questionnaires, consultation of medical records, pharmacy drug dispensing spreadsheets and the Ministry of Health's Logistics Drug System (Sistema Logístico de Medicamentos, SICLOM). The database contains all the drugs used by TB and HIV/AIDS patients on the date they were interviewed.
The collected data was stored in Microsoft Excel 2007 spreadsheets. Subsequently, the frequency of drug use was evaluated, combining the data with the TB and HIV/AIDS treatment phase that the patients were undergoing, with the associated diseases reported, as well as with the CD4+ T lymphocyte count and the viral load. The data was analyzed with the aid of the Statistical Package for the Social Science (SPSS) program, version 21.

For the proper classification and grouping of the drugs present in the database, the ATC (Anatomical Therapeutic Chemical) classification system was used, which divides the drugs into groups according to the system or organ that they act on and also according to their chemical, pharmacological and therapeutic properties. In this system, the drugs are classified according to a hierarchy of five distinct levels ranging from the anatomical group, through the therapeutic or pharmacological group that the drug is in, to the active ingredient at the $5^{\text {th }}$ level.

\section{Results}

The study included 81 adult coinfected patients, aged between 19 and 64 years old. The predominant age range was 30 to 39 years old (32\%), with a mean age of 40 . Of these patients, $62 / 81(77 \%)$ were male and 19/81 (23\%) female, Table 1.

Most of the interviewees, $64 / 81$ (79\%) used other medications to treat associated diseases, in addition to the treatment schemes for coinfection, averaging 1.5 associated diseases per patient. Most of these diseases were related to HIV and were considered Ols, Table 1.

We observed that $71 / 81$ (88\%) individuals were in the intensive phase of TB treatment, which lasts 2 months and 10/81 (12\%) individuals were in the maintenance phase of treatment, which lasts 4 months.

A total of 147 drugs and/or combinations of drugs used by patients in the treatment of coinfection and associated diseases were identified. The mean quantity of drugs used per patient was 10 , ranging from 2 to 20 drugs per patient. All the drugs were classified up to the ATC's $5^{\text {th }}$ level and their frequency of use was measured for later evaluation of the most prescribed drugs. From the prescription frequency of these drugs, a total value of 810 was found that refers to the sum of all the drugs prescribed and distributed among the 81 patients.

In Table 2, the most used groups of drugs, gathered by anatomical grouping according to the $1^{\text {st }}$ level of the ATC classification, were the anti-infectious for systemic use (group J), corresponding to $42 \%$, followed by the drugs that act on the food tract and metabolism (group A), 21\% and the nervous system (group N), corresponding to $16 \%$. These together accounted for $79 \%$ of the drugs used by the study patients.

When the most commonly used pharmacological groups were evaluated, considering the $3^{\text {rd }}$ level of the ATC, 99 (12\%) drugs classified to treat TB were found, $76(9 \%)$ antivirals of systemic action and 72 (9\%) corresponded to other analgesics and antipyretics (Table 2). The other pharmacological groups presented in Table 2 together with those already mentioned represented $80 \%$ of the drugs used by the patients in the study.

Regarding the classification at the $5^{\text {th }}$ level of ATC, the most used drugs were the following: RHZE scheme used by $57 / 81$ (70\%) individuals, followed by metoclopramide, administered in $52 / 81$ 
Table 1. Sociodemographic, clinical and pharmacotherapeutic characteristics of the patients coinfected with TB and HIV/AIDS (n=81).

\begin{tabular}{|c|c|c|c|c|}
\hline Variables & All n (\%) & $\begin{array}{c}\text { First-line TARV } \\
\text { patients n (\%) } \\
(\mathrm{TNF}+3 \mathrm{TC}+\mathrm{EFV})\end{array}$ & $\begin{array}{l}\text { Patients in other } \\
\text { TARV schemes } n(\%)\end{array}$ & $\begin{array}{c}\text { No scheme } \\
n(\%)\end{array}$ \\
\hline \multicolumn{5}{|l|}{ Sociodemographic } \\
\hline Male & $62(76.5)$ & $24(29.6)$ & $8(9.9)$ & $30(37.0)$ \\
\hline Single & $51(62.3)$ & $19(23.5)$ & $4(4.9)$ & $28(34.6)$ \\
\hline Has some income source & $70(86.4)$ & $26(32.1)$ & $9(11.1)$ & $35(43.2)$ \\
\hline Occupation & $58(71.6)$ & $22(27.1)$ & $8(9.9)$ & $28(34.6)$ \\
\hline Up to 8 years of schooling & $59(72.8)$ & $27(33.3)$ & $7(8.6)$ & 25 (30.9) \\
\hline \multicolumn{5}{|l|}{ Clinical } \\
\hline HIV diagnosis in up to one year & $44(54.3)$ & $15(18.5)$ & $3(3.7)$ & $26(32.1)$ \\
\hline Pulmonary TB & $46(56.8)$ & $16(19.8)$ & $6(7.5)$ & $24(29.6)$ \\
\hline Extrapulmonary TB & $27(33.3)$ & $12(14.8)$ & $4(4.9)$ & $11(13.6)$ \\
\hline Pulmonary + extrapulmonary TB & $8(9.9)$ & $3(3.7)$ & - & $5(6.2)$ \\
\hline \multicolumn{5}{|l|}{ Laboratory control } \\
\hline CD4+ T lymphocytes $<200$ cells $/ \mathrm{mm} 3$ & $59(72.8)$ & $24(29.6)$ & $8(9.9)$ & $27(33.3)$ \\
\hline Viral load > 10,000 copies/mL & $55(67.9)$ & $18(22.2)$ & $7(8.6)$ & $30(37.0)$ \\
\hline Undetectable viral load & $6(7.4)$ & $4(4.9)$ & $2(2.5)$ & - \\
\hline \multicolumn{5}{|l|}{ Opportunistic infections } \\
\hline Candidiasis & $20(25.0)$ & $5(6.2)$ & $4(4.9)$ & $11(13.6)$ \\
\hline Pneumocytosis & $19(23.4)$ & $3(3.7)$ & $4(4.9)$ & $12(14.8)$ \\
\hline Pneumonia & $9(11.1)$ & $3(3.7)$ & $1(1.2)$ & $5(6.2)$ \\
\hline Cytomegalovirus & $8(10.0)$ & $5(6.2)$ & - & $3(3.7)$ \\
\hline Syphilis & $5(6.2)$ & $2(2.5)$ & $1(1.2)$ & $2(2.5)$ \\
\hline Toxoplasmosis & $4(4.9)$ & $2(2.5)$ & - & $2(2.5)$ \\
\hline Herpes & $3(3.7)$ & $2(2.5)$ & - & $1(1.2)$ \\
\hline Cryptococcosis & $2(2.5)$ & $2(2.5)$ & - & - \\
\hline Others & $22(27.1)$ & $8(10.0)$ & $7(8.6)$ & $7(8.6)$ \\
\hline \multicolumn{5}{|l|}{ Pharmacotherapeutic } \\
\hline Pharmacotherapy with up to 9 medications & $18(22.2)$ & $5(6.2)$ & - & $13(16.0)$ \\
\hline Pharmacotherapy with 10 or more medications & $63(77.7)$ & $26(32.1)$ & $10(12.3)$ & $27(33.3)$ \\
\hline \multicolumn{5}{|l|}{ Treatment for ТВ } \\
\hline Basic TB treatment scheme (RHZE) & $69(85.2)$ & $28(34.6)$ & $7(8.6)$ & $34(42.0)$ \\
\hline Special scheme (Rifabutin, SOE, levofloxacin) & $12(15.0)$ & $3(3.7)$ & $3(3.7)$ & $6(7.4)$ \\
\hline
\end{tabular}

R: rifampicin; H: isoniazid; Z: pyrazinamide; E: ethambutol; S: streptomycin; O: ofloxacin; TNF: tenofovir; 3TC: lamivudine; EFV: efavirenz.

(64\%) patients, sulfamethoxazole + trimethoprim in 51/81 (63\%) patients, enoxaparin in 42/81 (52\%) patients, dipyrone injectable in $41 / 81$ (51\%) patients, and TNF+3TC+EFV in 31/81 (38\%) patients, Table 2.

The treatment for candidiasis, the most frequent $\mathrm{Ol}$ in the study after TB, was performed according to the recommendations of the Clinical Protocol and Therapeutic Guidelines (CPTGs) for management of HIV infection in adults, with administration of Fluconazole $150 \mathrm{mg}$ of ATC J02AC01. ${ }^{3}$ In this study, it was administered in 17 patients and is in the list of the 14 most used drugs, as shown in Table 2.

The treatment for pneumocytosis (PCP), the second most frequent Ol in the study, is performed with the use of sulfamethoxazoletrimethoprim (SMX-TMP) in association with a corticosteroid, in special cases, according to the clinical severity of the patient. After treatment, secondary prophylaxis is performed with SMX-TMP to prevent recurrence of the OI. ${ }^{3}$ In the present study the drug prednisone, of ATC H02AB07, was administered in 21 patients for the treatment of PCP. While SMX-TMP (J01EE01) was used by 51 patients to prevent the onset ( $1^{\text {st }}$ prophylaxis) and recurrence $\left(2^{\text {nd }}\right.$ prophylaxis) of PCP (Table 2).

\section{Discussion}

The publications evaluating the use of drugs in patients with TB and HIV/AIDS are incipient in Brazil and in the world, which makes it difficult to compare the studies regarding the proportion of drugs prescribed. What is observed in the literature are studies that address the clinical and epidemiological profile of infections $7-8,11,13-14$, factors that compromise treatment adherence ${ }^{12,15-17,26}$ and the incidence of Ols. ${ }^{18-20}$

In this study, the drugs prescribed for 81 patients coinfected with TB and HIV/AIDS were evaluated and classified. The male patients made up $77 \%$ of the sample. The predominance of males in both TB and HIV/ AIDS infection has also been described in other studies conducted in different locations in Brazil, confirming the male population as more vulnerable and prevalent for coinfection. . $^{7,12-13,17,26}$

The age group of the studied individuals followed the same predominance (30 - 39 years old) of studies conducted in Porto Alegre/Rio Grande do Sul by Rodrigues et al (2010). ${ }^{15}$ and in Fortaleza/Ceará by Lemos et al (2016). ${ }^{17}$ As for the mean age of the coinfected patients (40 years old), it was similar to the study described by Neves et al (2012). ${ }^{12}$ in Ribeirão Preto/São Paulo, and by Moriel et al.(2011), ${ }^{26}$ in Campinas/São Paulo. 
Table 2. Distribution of the pharmacological groups of the most used drugs, according to the ATC classification ( $n=810)$ and the frequency of patients using or not using ART $(n=81)$.

\begin{tabular}{|c|c|c|c|c|}
\hline Therapeutic, pharmacological group or drug according to ATC & All n (\%) & $\begin{array}{c}\text { First-line TARV patients } \\
n(\%)\end{array}$ & $\begin{array}{l}\text { Patients in other TARV } \\
\text { schemes } n(\%)\end{array}$ & $\begin{array}{c}\text { No scheme } \\
n(\%)\end{array}$ \\
\hline \multicolumn{5}{|l|}{ Therapeutic Groups } \\
\hline Anti-infective agents for systemic use (J) & $340(42.0)$ & $30(37.0)$ & $11(13.6)$ & $40(49.4)$ \\
\hline Feeding tract and metabolism (A) & $174(21.5)$ & $29(35.8)$ & $12(14.8)$ & $35(43.2)$ \\
\hline Nervous system (N) & $131(16.1)$ & $24(29.6)$ & $10(12.3)$ & $34(42.0)$ \\
\hline Blood and hematopoietic organs (B) & $66(8.2)$ & $19(23.5)$ & $9(11.1)$ & $23(28.4)$ \\
\hline Hormones for systemic use $(\mathrm{H})$ & $30(3.7)$ & $7(8.6)$ & $7(8.6)$ & $15(18.5)$ \\
\hline Dermatological (D) & $16(2.0)$ & $6(7.4)$ & $5(6.1)$ & $2(2.5)$ \\
\hline Antiparasitic, insecticides and repellents $(P)$ & $14(1.7)$ & $5(6.1)$ & $1(1.2)$ & $7(8.6)$ \\
\hline Respiratory system (R) & $13(1.6)$ & $6(7.4)$ & - & $4(4.9)$ \\
\hline Cardiovascular system (C) & $11(1.4)$ & $3(3.7)$ & $3(3.7)$ & $2(2.5)$ \\
\hline Sensory organs (S) & $7(0.9)$ & $4(4.9)$ & $1(1.2)$ & - \\
\hline Several (V) & $8(1.0)$ & $3(3.7)$ & $1(1.2)$ & $4(4.9)$ \\
\hline \multicolumn{5}{|l|}{ Pharmacological groups } \\
\hline Medications to treat tuberculosis (J04A) & $99(12.2)$ & $30(37.0)$ & $11(13.6)$ & $40(4.9)$ \\
\hline Systemic action antiviral (J05A) & $76(9.3)$ & $30(37.0)$ & $11(13.6)$ & $3(3.7)$ \\
\hline Other analgesics and antipyretics (N02B) & $72(8.9)$ & $24(29.6)$ & $10(12.3)$ & $24(29.6)$ \\
\hline Propulsive (A03F) & $63(7.8)$ & $22(27.2)$ & $9(11.1)$ & $31(38.3)$ \\
\hline Sulphonamides and trimethoprim (J01E) & $57(7.0)$ & $33(40.7)$ & $5(6.1)$ & $29(35.8)$ \\
\hline Antithrombotic agent $(\mathrm{B} 01 \mathrm{~A})$ & $49(6.1)$ & $19(23.4)$ & $8(9.9)$ & $21(25.9)$ \\
\hline Other simple vitamins $(\mathrm{A} 11 \mathrm{H})$ & $41(5.1)$ & $15(18.5)$ & $10(12.3)$ & $16(19.8)$ \\
\hline Macrolides, lincosamides, and streptomycins (J01F) & $38(4.7)$ & $15(18.5)$ & $4(4.9)$ & $17(21.0)$ \\
\hline Peptic ulcer drugs (A02B) & $35(4.3)$ & $12(14.8)$ & $8(9.9)$ & $15(18.5)$ \\
\hline Systemic-use corticosteroids (H02A) & $28(3.4)$ & $6(7.4)$ & $6(7.4)$ & $15(18.5)$ \\
\hline Antiepileptics (N03A) & $23(2.8)$ & $8(9.9)$ & $3(3.7)$ & $9(11.1)$ \\
\hline Systemic-use antimycotic (J02A) & $19(2.3)$ & $5(6.1)$ & $4(4.9)$ & $10(12.3)$ \\
\hline Other beta-lactam antibacterials (J01D) & $13(1.6)$ & $3(3.7)$ & $4(4.9)$ & $6(7.4)$ \\
\hline Opioids (N02A) & $13(1.6)$ & $2(2.5)$ & $1(1.2)$ & $10(12.3)$ \\
\hline Others & $184(22.7)$ & $23(28.4)$ & $11(13.6)$ & $26(32.1)$ \\
\hline \multicolumn{5}{|l|}{ Medications } \\
\hline RHZE 150+75+400+275 (J04AM06) & $57(7.0)$ & $21(25.9)$ & $6(7.4)$ & $30(37.0)$ \\
\hline Metoclopramide $5 \mathrm{mg} / \mathrm{mL}$ (A03FA01) & $52(6.4)$ & $19(23.5)$ & $9(11.1)$ & $24(29.6)$ \\
\hline Sulfamethoxazole+trimethoprim 400+80 mg (J01EE01) & $51(6.3)$ & $20(24.7)$ & $5(6.1)$ & $25(30.7)$ \\
\hline Enoxaparin $40 \mathrm{mg}(\mathrm{B} 01 \mathrm{AB} 05)$ & $42(5.2)$ & $16(19.8)$ & $7(8.6)$ & $19(23.5)$ \\
\hline Pyridoxine 40 mg (A11HA02) & $41(5.1)$ & $15(18.5)$ & $10(12.3)$ & $16(19.8)$ \\
\hline Dipyrone 500 mg/mL (N02BB02) & $41(5.1)$ & $16(19.8)$ & $9(11.1)$ & $16(19.8)$ \\
\hline TNF+3TC+EFV (J05AR11) & $30(3.7)$ & $30(37.0)$ & - & - \\
\hline Azithromycin 500 mg (J01FA10) & $25(3.1)$ & $13(16.1)$ & $3(3.7)$ & $9(11.1)$ \\
\hline Prednisone 20 mg (H02AB07) & $21(2.6)$ & $5(6.1)$ & $5(6.1)$ & $4(4.9)$ \\
\hline Dipyrone 500 mg (N02BB02) & $20(2.5)$ & $8(9.9)$ & $1(1.2)$ & $11(13.6)$ \\
\hline Omeprazole 20 mg (A02BC01) & $18(2.2)$ & $6(7.4)$ & $4(4.9)$ & $9(11.1)$ \\
\hline Fluconazole 150 mg (J02AC01) & $17(2.1)$ & $5(6.1)$ & $2(2.5)$ & $10(12.3)$ \\
\hline Clonazepam 2.5 mg/mL (N03AE01) & $16(2.0)$ & $4(4.9)$ & $3(3.7)$ & $9(11.1)$ \\
\hline Ethambutol $400 \mathrm{mg}$ (J04AK02) & $14(1.7)$ & $4(4.9)$ & $4(4.9)$ & $7(8.6)$ \\
\hline Others & $363(44.8)$ & $31(38.3)$ & $12(14.8)$ & $40(49.9)$ \\
\hline
\end{tabular}

A large part of the TB/HIV association is concentrated in the economically active age group ( $15-50$ years old) due to the greater exposure of this group to activities carried out in this phase of life, becoming important to direct policies to control coinfection to these individuals. ${ }^{15}$

In addition to TB, HIV-related Ols accounted for $67 \%$ of the reported diseases and emerged as a consequence of immunodeficiency characterized by low levels of LT-CD4+ $\left(<200\right.$ cells $\left./ \mathrm{mm}^{3}\right) \cdot{ }^{13,18,20-22}$ The frequency of Ols throughout HIV infection is understandable as the virus infects the cells that are part of the body's defense system, causing the progression of immunosuppression with consequent development of these infections. ${ }^{18}$

Dias et al (2018). ${ }^{20}$ analyzed the medical records of 534 patients diagnosed with HIV, followed up at a reference hospital in Jataí/ Goiás and it was found that the Ols mainly affected individuals with a low LT-CD4+ count, and that the mean count of these cells in patients with and without Ols in the values of 255 and 433 cells/ $\mathrm{mm}^{3}$ respectively.

The high number of drugs used by the patients may be justified by the number of associated diseases described in the study and 
the need for OI prophylaxis. Polypharmacy is well described in older adult patients, but recently it has been a concern among PLHIV care providers. In addition to the combination of ART, which generally consists of at least three drugs, and the use of anti-TB medications, which involves at least four drugs, coinfected patients are increasingly administering drugs to treat associated diseases, increasing the complexity of therapy. ${ }^{23}$

Ols prophylaxis, which is performed from the reduced LT-CD4+ count, represents an important strategy to optimize therapeutic results. ${ }^{21}$ Candidiasis and PCP are Ols that commonly affect patients with HIV immunosuppression. ${ }^{5,19-20}$ In the study by Spezia et al (2015).. ${ }^{18}$ performed in a hospital in Indaiatuba/São Paulo, $73 \%$ of the diseases presented by the evaluated population were Ols, the most frequent being candidiasis and PCP.

In addition to the reduced LT-CD4+ count, most of the studied individuals showed a high viral load, testifying the literature and indicating that TB and other Ols are associated with immune system impairment and reduced survival of coinfected patients. ${ }^{12-13,17}$

The most frequent clinical form of TB in the study was pulmonary (57\%). This finding was similar to other studies conducted with coinfected patients. ${ }^{7-8,13}$ However, the association between TB and HIV in immunocompromised individuals presents different characteristics and TB may manifest in atypical clinical forms of extrapulmonary character, as was observed in other patients of the study. ${ }^{15}$

When the most commonly used therapeutic groups were evaluated, the anti-infectious for systemic use, with the ATC I classification, stood out as the main ones in the study. This finding is consistent with what was expected, as the study's inclusion criterion was the diagnosis of TB and HIV/AIDS, along with the initiation of TB treatment in the data collection month. The $\mathrm{J}$ therapeutic group covered the drugs used in the treatment scheme of TB, HIV/AIDS and also the antimicrobials prescribed for the treatment and prevention of Ols.

The drugs used in the food tract and metabolism, A-classified, were the second most used therapeutic group because this group includes the drugs prescribed to minimize the common adverse gastrointestinal reactions in the treatment of TB, such as nausea and vomiting. ${ }^{16-24}$

In the assessment of the pharmacological groups by the $3^{\text {rd }}$ level of the ATC, the J04A subgroup, which corresponds to the drugs used to treat TB, presented itself as the most frequent. This is as expected since the drugs that make up the TB treatment scheme are part of the same J04A pharmacological group and all the study participants had initiated TB treatment according to the preestablished inclusion criteria.

The RHZE scheme, of ATC J04AM06, was the most used by the study population and this indicates that the therapy has been effective with a first-line scheme, with no need for adjustments in pharmacotherapy due to possible intolerances.

Pyridoxine, classified as $\mathrm{A} 11 \mathrm{HA} 02$, was the $5^{\text {th }}$ most used drug in the study with the indication of prevention of peripheral neuropathy. Peripheral neuropathy arises as a result of immunosuppression caused by HIV or as an adverse effect of ART. Pyridoxine is also associated with isoniazid in the treatment of TB because this drug presents a certain degree of toxicity to the nervous system, being the peripheral neuropathy the most common reaction. ${ }^{5-6}$

The scheme formed by TNF+3TC+EFV, of ATC J05AR11, was prescribed for 30 patients in the study, raking $7^{\text {th }}$ on the list of most prescribed drugs. A small proportion of individuals made use of the second line of HIV treatment because they were intolerant to EFV. Not all patients were on ART because some of them were beginning treatment for TB. This represents the late diagnosis already with AIDS-defining diseases. According to the CPTGs, for the management of HIV in adults, ART can only be started two weeks after starting TB treatment if the LT-CD4+ count is less than 50 cells $/ \mathrm{mm},{ }^{3}$ or after eight weeks, at the end of the intensive care phase for the other patients, which justifies the portion of patients who were not using ART. ${ }^{5}$

Given the results found, it is important to emphasize that the knowledge of the presence of coinfection, together with the studies of drug use, are important for the proper monitoring of patients, since numerous prescribed drugs are involved, less adherence to treatment, resistance to drugs and higher mortality rate.

The treatment of coinfection requires a differentiated follow-up that allows the therapeutic integration aimed at the prevention of HIV-related diseases, as well as better monitoring of adverse reactions and adjustments in pharmacotherapy, optimizing the response of both treatments. ${ }^{25}$

The limitation of this study is the collection of one-off data and its conduction in only one reference hospital for infectious diseases, and it cannot have the results generalized, which suggest the need to conduct more in-depth studies of drug use in coinfected patients to direct actions applied to promote the rational use of drugs.

\section{Conclusion}

The mean number of drugs per patient remained high due to the treatment schemes used to treat coinfection and also due to the numerous associated diseases and the need for Ol prophylaxis.

The most used therapeutic groups were those of the antiinfectious agents, considering the great number of Ols presented by coinfected patients, followed by the food tract medications used to treat the adverse drug reactions.

The study participants had LT-CD4+ count levels below 200 cells/ $\mathrm{mm}^{3}$ and a high VC, indicating advanced immunodeficiency.

Therefore, in order for TB to be effectively treated and prevented in coinfected individuals, it is necessary to develop specific actions aimed at these patients, such as specialized care, early diagnosis of both diseases, timely implementation of ART and training of professionals to properly guide patients.

It is also important to develop more EUMs that provide information on the profile of drug use among coinfected patients so that other strategies can be established to promote the rational use of drugs in this population, with consequent improvement in the quality of life of coinfected individuals.

\section{Funding sources}

The research has not received any funding.

\section{Collaborators}

ISL, WSC, and NHR built the study design, analyzed and interpreted the data, wrote, read, and approved the final version to be published, and are responsible for all the information in the paper, ensuring the accuracy and integrity of any part of the work. 


\section{Acknowledgments}

To the Hospital Foundation of the State of Minas Gerais (Fundação Hospitalar do Estado de Minas Gerais, FHEMIG) / Eduardo de Menezes Hospital for their support.

\section{Conflict of interest statement}

The authors declare that there are no conflicts of interest in this article.

\section{References}

1. UNAIDS. Relatório Informativo - Dia Mundial Contra a AIDS 2018. Internet. Available from https://unaids.org.br/wp-content/uploads/2018/11/Fact-sheet-UNAIDS-novembro-2018. pdf. Accessed on 27 nov 2018.

2. World Health Organization (WHO). Global Tuberculosis Report. Geneva: World Health Organization; 2018.

3. Ministry of Health (BR). Coinfecção TB-HIV no Brasil: panorama epidemiológico e atividades colaborativas. Brasília: Ministério da Saúde; 2018.

4. Fujiwara PI, Dlodlo RA, Ferroussier O, et al. Implementando atividades colaborativas TB-HIV: Um Manual Programático. Paris, França: União Internacional contra Tuberculose e Doenças Respiratórias (A Union). 2012. Internet. Available from https://www.theunion.org/whatwedo/publications /technical/portugese/Union- HIV-TB_portuguese_29jun13.pdf Accessed on 27 nov 2018.

5. Ministry of Health (BR). Protocolo clínico e diretrizes terapêuticas para manejo da infecção pelo HIV em adultos. Brasília: Ministério da Saúde; 2018.

6. Ministry of Health (BR). Guia de Vigilância em Saúde - 1. ed. atual. Brasília: Ministério da Saúde; 2016.

7. Saita NM, Oliveira HB. Tuberculose, AIDS e coinfecção tuberculose-AIDS em cidade de grande porte. Rev. Latino-Am. Enfermagem. 2012;20(4):08. Internet. Available from https:// www.eerp.usp.br/rlae. Accessed on 20 nov 2018.

8. Carvalho LGM, Buani AZ, Zollner MSAC, et al. Co-infecção por Mycobacterium tuberculosis e vírus da imunodeficiência humana: uma análise epidemiológica em Taubaté (SP). J Bras Pneumol. 2006; 32(5):424-9.

9. Elo DO, Ribeiro E, Storpirtis S. A importância e a história dos estudos de utilização de medicamentos. Rev. Bras. Cienc. Farm. 2006;42(4):475-485.

10. Costa CMFN, Silveira MR, Acurcio FA, et al. Utilização de medicamento pelos usuários da atenção primária do Sistema Único de Saúde. Rev Saude Publica. 2017;51(supl 2):18s.

11. Jamal LF, Moherdaui F. Tuberculose e infecção pelo HIV no Brasil: magnitude do problema e estratégias para o controle. Rev Saúde Pública. 2007;41(supl. 1):104-110.

12. Neves LAS, Canini SEM, Reis RK, et al. AIDS e tuberculose: a coinfecção vista pela perspectiva da qualidade de vida dos indivíduos. Rev Esc Enferm USP. 2012;46(3):704-10.

13. Miranda AE, Golub JE, Lucena FF, et al. Tuberculosis and AIDS
Co-Morbidity in Brazil: Linkage of the Tuberculosis and AIDS Databases. Braz J Infect Dis. 2009; 13(2):137-141.

14. Gaspar RS, Nunes N, Nunes M, et al. Análise temporal dos casos notificados de tuberculose e de coinfecção tuberculose-HIV na população brasileira no período entre 2002 e 2012. J Bras Pneumol. 2016; 42(6): 416-422.

15. Rodrigues JLC, Fiegenbaum M, Martins AF. Prevalência de coinfecção tuberculose/HIV em pacientes do Centro de Saúde Modelo de Porto Alegre, Rio Grande do Sul. Sci Med. 2010; 20(3): 212-217.

16. Oliveira JF, Antunes MBC. Abandono anunciado ao tratamento da tuberculose em uma unidade de Saúde da família do recife- a perspectiva do usuário. Ver APS. 2012;15(1):4-13.

17. Lemos LA, Fuiza MLT, Reis RK, et al. Adesão aos antirretrovirais em pessoas com coinfecção pelo vírus da imunodeficiência humana e tuberculose. Rev. Latino-Am. Nursing. 2016;24:e2691.

18. Spezia LP, Picarelli MEA, Santos ABR. Avaliação da AIDS e da ocorrência de doenças oportunistas e sexualmente transmissíveis em pacientes infectados pelo HIV residentes na região de Indaiatuba, SP. J Health Sci Inst. 2015;33(4): 303-8.

19. Huang YS, Yang JJ, Lee NY, et al. Treatment of Pneumocystis jirovecii pneumonia in HIV-infected patients: a review. Expert Rev Anti Infect Ther. 2017; 15 (9):873-892.

20. Dias RFG, Bento LO, Tavares C, et al. Epidemiological and clinical profile of HIV-infected patients from Southwestern Goias State, Brazil. Rev Inst Med Trop São Paulo. 2018;60:e34.

21. Forda N, Meintjesb G, Vitoria M, et al. The evolving role of CD4 cell counts in HIV care. Curr Opin HIV AIDS. 2017;12:123128.

22. Maruza M, Ximenes RAA, Lacerda HR. Desfecho do tratamento e confirmação laboratorial do diagnóstico de tuberculose em pacientes com HIV/AIDS no Recife, Pernambuco, Brasil. J Bras Pneumol. 2008; 34(6): 394-403.

23. Smith JM, Flexner C. The challenge of polypharmacy in an aging population and implications for future antiretroviral therapy development. AIDS. 2017;31(supl 2): S173-S184.

24. Souza MVN, Vasconcelos TRA. Fármacos no combate à tuberculose: passado, presente e futuro. Quim. Nova. 2005; 28(4): 678-682.

25. Sinshaw $Y$, Alemu S, Fekadu A, et al. Successful TB treatment outcome and its associated factors among TB/HIV co-infected patients attending Gondar University Referral Hospital, Northwest Ethiopia: an institution based cross-sectional study. BMC Infect Dis. 2017;17(1): 132.

26. Moriel P, Carnevale RC, Costa CGR, et al. Efeitos das intervenções farmacêuticas em pacientes HIV positivos: influência nos problemas farmacoterapêuticos, parâmetros clínicos e economia. R. Bras. Farm. General Serv. Saúde. 2011; 2(3): 5-10. 